\title{
The Personal is Political: A Feministic Analysis of Pakistani Political Autogynographies
}

\author{
Mujahid Abbas \\ Lecturer, Department of Humanities, COMSATS University Islamabad, Vehari Campus \\ mujahid@cuivehari.edu.pk \\ Asma Kashif Shahzad \\ Assistant Professor, Department of Humanities, COMSATS University Islamabad, Vehari \\ Campus \\ asmashahzad@cuivehari.edu.pk
}

\begin{abstract}
This present research analyses Benazir Bhutto's Daughter of the East (1989) and Fatima Bhutto's Songs of blood and sword: A daughter's memoir (2011) to explore how Pakistani women, belonging to elite political families, are politically conscious while engaging their fathers' stories in their autobiographies. The autobiographies share specific characteristics: both the narrators belong to the same Bhutto family, and their self-narratives are predominantly father clear; both texts are written after their fathers' political assassination, and the narrators have tried to defend their father's political vulnerable image; the word "daughter" in each of the subtitles emphasizes the idea of filiation. The narrators reflect their political consciousness by defending and praising their fathers' political actions and elaborate on how national politics' political implications have affected their personal and political familial lives. Highlighting the importance of political education, Benazir distrusts outdated politics of compromises and narrates that the political profession requires sacrifices. Being a politician, one has to compromise even with the murderers of one's (her) father. Benazir condemns patriarchy and mentions that daughters can inherit their father's political legacy like sons. Meanwhile, Fatima criticizes Benazir that she is the usurper of her father's political legacy and does not follow her political principles. Fatima's self-narrative challenges Benazir's political claims made in her autobiography. Both the narrators look gendersensitive and condemn patriarchy even though both of them try to defend their fathers. Benazir and Fatima discuss their personal and private matters publicly for political reasons, as manifested through the text.
\end{abstract}

Keywords: Autobiography, Political consciousness, Personal and Political, Second Wave of Feminism 


\section{Introduction}

The autobiographers, Benazir Bhutto and Fatima Bhutto, belong to the same Bhutto family clan under my study. Benazir, the former prime minister of Pakistan, is Zulfikar Ali Bhutto, a Pakistani politician who has served as President of Pakistan from 1971 to 1973 and then as a Prime Minister of Pakistan from 1973 to 1977. Zulfikar was caught by Zia's military regime and was executed in 1979 to authorise the murder of his political opponent, Ahmad Raza Khan Kasuri. Benazir takes over the PPP (Pakistan Peoples Party), her father's political party, after her father's death. She repeatedly imprisoned by the military coup and then exiled to Britain in 1984. She returned to Pakistan in 1986 and strengthened PPP from socialist to a liberal one that led her to victory in the 1988 election. Benazir has served as Prime Minister of Pakistan from 1988 to 1990 and again from 1993 to 1996. Fatima is the niece of Benazir and the daughter of Mir Murtaza Bhutto. Murtaza, Benazir's brother, was accused in approximately one hundred cases by the Pakistani government under general Zia's military regime. Majorly he was alleged to making a terrorist organisation, Al-Zulfikar, which attempts on the life of available Zia, and was accused in the high jacking of a plane. After a long self-exile when Murtaza returned to Pakistan under his sisters', Benazir's, government, shot dead before their residence 70 Clifton, Karachi. Forgetting all the accusations of her father, Fatima cries out at her father's death and starts an investigation into the matters of her father's life and death. Announcing Benazir usurper, Fatima claims that her father is the rightful inheritor of Bhutto's political legacy. Fatima and Benazir have many points in common in their narratives. Simultaneously, justifying their fathers' personal and political actions, both the narrators record and comment on the appalling history of Pakistan. Both the daughters reflect their political understanding while writing their fathers' political lives in a broader Pakistani political context.

Under its classic banner, "The personal is political", the second wave of feminism led the charge for access to equal pay for equal work, child care, abortion rights and recognition of unpaid labour (Seely, 2007, pp. 38-39). The personal matters (childbirth, abortion rights, marriages and family life etc.) are no more personal because the limitation on personal issues also limits women's rights. This idea is taken from the second wave of feminism (1960s) that raised the slogan "personal is political". The present study signifies that personal matters should 
be personal and not discussed in public are wrong. Personal life and its issues have political implications. In short, personal and political spheres affect each other and are overlapping.

The term autogynography stands for the only autobiographies written by women. In feminist terms, the kind of autobiography under the present study may be categorized as atuogynography that is a term that Domna Stanton uses in the 1980s for the recognition of autobiographies written by females. In The Female Autograph (1984), she brings to light the canonical recognition of female's autobiographies with male's writing. Furthermore, the infix 'gyno' in the word autobiography emphasizes that the autobiographies written by females deal with the only problems and difficulties faced by women.

\section{Theoretical Framework of the Study}

This paper aims at to evaluate the political consciousness of Pakistani elite women from the perspective of "the personal is political", a second wave feminist slogan, developed mainly through the concept of intertextuality by reading Julia Kristeva's canonical book "Desire in Language: A Semiotic Approach to Language and Art" (1980). Intertextuality is the reference of a social, media or literary text within another social, media or literary text. Kristeva's concept of intertextuality is a revision or rework of Bakhtin's notion of dialogism. According to Bakhtin all discourses are in dialogue with each other rather, they are prior discourses or the discourses yet to come. Dialogism is consisted on the dialogue between individuals, instead they are the authors or the characters of a literary text in a specific given context and social settings of that time (Panchappa, 2011).

Women gather together during the second wave of feminism and engaged in what is known as "consciousness raising (CR)" (Royce, 2011, p. 532). While sharing their personal, they have uncovered their stories' commonalities that made them understand their subjugation by the social structures (Royce, 2011, p. 532; Tong, 2009, P. 48; Allen, 2000, p. 280; Rosen, 2000, p. 197). Second wave feminism embraced the premise of consciousness-raising to realise that the experiences of women that were understood as personal and private were connected to different forms of gender inequality and oppression; realisation of this fact made possible the analysis of political and collective actions. Lee (2007) mentions that "as a focal point of second-wave activism, consciousness-raising was the first step toward women's emancipation from patriarchy, 
which feminists deemed ubiquitous" (p. 165). According to Lee, consciousness-raising was the first step in forming women's independent thought without any influence of patriarchy. Those small groups have given women an identity separate from men. They were free to share their experiences as an independent thinker rather than as stereotypical object in the patriarchal society. Women started recognising their social worth and their deserved place in society. Allen (2000) emphasised that women should teach themselves "to think independently" so that they can achieve more than that of therapeutic relief (pp. 280-281). The principal purpose of consciousness-raising was to develop a theory that was "rooted in concrete experience" (p. 277). The formation of the theory was vital because it aided the apprehension of totality of the female's condition.

The most important contribution of the second wave of feminism was the slogan "the personal is political" that has captured the most controversial and distinctive problem of politicising the lives of ordinary women. The slogan "the personal is political" was first coined by a feminist activist and civil right worker Carol Hanisch (2000), in 1968. Rosan (2000) notes, "by this, she [Hanisch] meant to convey the then shocking idea that there were political dimensions to private life, that power relation shaped life in marriage, in the kitchen, the bedroom, the nursery, and at work" (p. 196).

Second wave feminists insisted that among the other oppressions of women, the primary and fundamental oppression is men's control over women's self-esteem, self-identity and selfrespect. The second wave of feminism that is started in 1960's emphasised the personal and political which means that, like men women also have their own free will and choice to share their personal and private matters in public (Mortenson, 2011, pp. 529-530; Tong, 2009, p. 49; Seely, 2007, pp. 38-39; Williams, 2001, p. 94; Walters, 2005, p.137). The word political here means what to share in the public and what to hold.

\section{Analysis of Daughter of the East}

The autogynographers have incorporated multiple voices in their narratives while contesting their fathers' authentic image. Benazir has written almost two-third of the book Daughter of the East (1989) from her own memory and there is short time lapse between the occurrence of the events and her narration. She narrates her struggle for power and democracy 
soon after its success. She depends on her memory to report the events she experienced. However, she narrates only those events that have some meaning in the "contemporary context" (Passerini, 1987, p. 127). She intends to validate her narrative by introducing other voices. Smith and Watson (1998) state that Bakhtin's theory of dialogism support the claim of multiple voices in autobiographical texts (p. 30). Though the life narratives are biased and written to glorify father, Benazir includes numerous voices in her narrative to validate her father's positive image. She has in her narrative the voice of her father, party workers, political friends, political leaders around the world, political prisoners, army officers and the voice of her mother. Besides interviews of individuals belonging to different spheres of life, she includes letters, historical references, references from the Noble Quran, instances from the life of Prophet Muhammad (PBUH). Various other voices accompany the voice of Benazir in the construction of her father's as well as her own identity. Other voices in the narrative co-construct and glorify both the father and the daughter's images. Benazir relates herself to different personalities and their attributes to identify with them. Although her book is dedicated to her father yet she claims herself to be the daughter of the whole East.

The technique of compare and contrast marks Benazir's narrative. Benazir identifies herself with different religious characters to construct her Muslim identity. She compares and identifies her personal traits with those of Bibi Khadija (R.A.), Bibi Zeinab (R.A.) and Bibi Aisha (R.A.). She employs religious discourse to glorify her father's image since she labels her father as a mystic and a martyr. While constructing her political identity, she alludes to the contemporary political discourse and relates herself to Indira Gandhy, Sirimavo Bandaranaike and Fatima Jinnah. On account of her political achievements, she compares herself with Indira Gandhy. Being a victim father's daughter, she compares herself with Kathleen Kennedy and Mujib's daughters. She contrasts her father's governance period to Zia's period of dictatorship and points out the differences. She praises her father and gives historical references that Yahya Khan, a military dictator, asked her father "to save Pakistan" when Dacca was about to fall in the war of 1971 (p. 55). She contrasts her father's political credibility to Nixon's, an American president, who loses his "credibility" and was "hated" by his people (p. 73). 
Further, she narrates in confessional form and accepts her heart's dark motives. She confesses the political tactics that she uses to overturn Zia's dictatorship. She says to her party members, "let's go to the mazaars to pray . . . believing the regime which was pounding IslamIslam-Islam into everyone's heads wouldn't dare arrest us while we prayed at the tombs of our saints" (p. 125). Her narrative takes turn from daughter's father perspective to father's daughter perspective. She praises her father and is proud of his political achievements and the fact that she is being identified concerning her father.

Benazir's narrative reflects her political understanding and consciousness. She asserts that political profession requires sacrifices and being a politician, one has to compromise even with the murderers of one's (her) father. She criticises self-centeredness in politics and does not compromise on merit for the party's political decisions. She states that political education is necessary to keep pace with politics's risky life. She confesses her diplomatic decisions in her narrative. She recounts her father's political victories and mentions her own political insights. After her father's death, she was forced to accept whatever was happening at that time in national politics. She makes compromises with Zia's military regime and says "fine" to their terms (p. 25). "Consciousness-raising" as the focal point of second wave of feminism is the first step toward women's liberation from patriarchy (Lee, 2007, p. 165). Politically conscious Benazir takes the diplomatic path to defeat the dictatorship. She is well aware of the regime's power and does not want to give it a pretext to harm her political aspirations since she believes that politics does not remain a "one side" game (p. 301). She adopts a "strategy" that does not directly antagonise the regime, because she does not want the regime to disrupt her political plans. In a way, she has no other choice but to come to terms with the regime.

Benazir stresses on the importance of political education and understanding and distrusts the outdated political system. Sluga (2014) is of the view that we can't let our "prejudices fall aside in our flight upward" to pure reflective thought (p. 166). He continues that our shared prejudices are themselves political that inevitably occur in our minds. Benazir believes the politics which is free from "prejudices" and shortsightedness (Benazir, 1989, p. 62). Her narrative is filled with prejudice against the military regime that started at the time of her father's imprisonment that further heightened by her father's hanging. She belongs to "new generation" 
and wants to forget the complexes and disagreements of past generations and condemns the selfcentered old political leaders in her who take her as "a silly little girl" (p. 26). She does not take undue political advantage by using any unfair means. She does not want to do politics at the cost of her father's name as she denies all together her uncle Murtaza's suggestion to exhume the body of her father for political gains, but she refuses since "now he's free. Let him rest in peace" (p. $15)$.

Benazir understands more about Pakistan while studying government at Harvard rather than living there. She gives importance to the political actions and decisions authorised by the law. She takes part in the party's political decisions and speaks her mind. After assessing the country's political temperature, she makes her decisions with confidence. She argues that the politics is a game of "confidence" if someone loses it, defeat will be the fate (p. 26). Like Mukhtar Mai, Benazir emphasises education that it is the only way to recognise one's own rights and duties. Education makes one conscious to one's political consciousness and gives the confidence to claim one's rights. Benazir has gained confidence in politics due to her degrees in government from Harvard and Oxford and from the political lessons taught by her father that were based on his experience. She learns that it is the constitution that enforces laws in the country. She supports the politics of law and does not compromise on "merit" (p. 267) without caring if somebody leaves the party or remains in the party. She withholds that "nothing is permanent" in politics (p. 269). People join and leave the party but she does not compromise on merit. Benazir is conscious about the risks involved in politics but she argues that the "emancipation of the people of Pakistan" is more important for her than anything else (p. 243). She counts her political sacrifices for the people and does not hesitate to go into "prison" to better people (p. 243).

Widmalm (2016) affirms that her father urged her to come into politics and finally to act upon his advice she sacrifices everything for Pakistan in the form of her death. She wisely uses the political tactics of opposition while criticising them. When Zia was introducing Islamization in Pakistan and public meetings were banned, she suggests, "let's go to the mazaars to pray . . . believing the regime which was pounding Islam-Islam-Islam into everyone's heads wouldn't dare arrest us while we prayed at the tombs of our saints" (p. 125). She is aware of her weak political 
position and tries to sound as "calm" as possible to keep pace with those old members whom she refers as "old uncles" in her narrative (p. 267). She mentions in her narrative the greed and selfcenteredness of old political party members. Raza (2014) notes that Zulfikar's children were ditched by the loyalist "uncles" of the party. Raza continues that Benazir was wary of old uncles and taught her children to beware of opportunist uncles who pose to be their companions. She always values the democratic perspective in her political decisions and makes it the party's slogan. She develops consensus among her party members. She does not force decisions on the party members but puts forward her thoughts and let other members of the party "decide" (p. $330)$.

In Benazir's narrative, the male characters are found dependent on a brave female. Benazir looks at defending her father and brothers in the course of narrative literally. She wants to be with her father to protect him when commandos get into their house for Mr. Bhutto. After the arrest of her father her younger brother Shah was also held by the army who asks Benazir for help and she "shouts" at the soldier to leave him, that he is her brother (p 107). She takes the dead body of her brother Shah in Pakistan by risking her own life to fulfill his lost wish, to be buried in Pakistan. Benazir tirelessly fights the "trumped-up charges" (p. 5) against her father by Zia's military regime and she is brave enough to face death for the survival of her father's concept of "democracy" (p. 196).

Although Benazir is raised with "no discrimination" to her brothers (p. 32) and has brought up in a family that gives equal chances to boys and girls yet, she senses the patriarchal thought of the community she was living in. She condemns patriarchy and male "chauvinistic" thought (p. 65), but her narrative is not free from patriarchal effects. Tong's (2009) argues that women cannot experience themselves as unique being because of the "sexual status, role, and temperament" that is constructed under patriarchy (p. 52). Benazir's personal life is also affected by the patriarchy. She narrates that the male chauvinistic thought also drives her marriage decision, that a single woman is a "suspect" in a male patriarchal society (p. 353). Her decision of marriage was the sacrifice of her personal freedom. She decides to marry with the purpose to 
put down the unspoken reservations that a single woman might be too "neurotic to lead the country, or too aggressive, or too timid" (p. 353).

Benazir herself becomes an iconic figure in front of the whole world because at first she is the "first woman ever elected head of an Islamic nation". Secondly, she fights a brave political war with the military dictator and restores democracy (Derr, MacNair \& Naranjo-Huebl, 2005, p. 320). Skard (2015) mentions that Benazir's official visits with her infant boy symbolise "beauty, power and motherhood" (p. 128). Benazir condemns the negative gender stereotypes attached to women. The female characters in her narrative are courageous and determinant, like men. She recalls Begum Rana's determination who resists wild beatings and refuses to give false testimony that Benazir is a member of Al-Zulfikar, a terrorist organisation. Begum Bhatti confesses, in her interview, that army officers "held cigarettes to our arms until we could smell the burning of our own flesh" (p. 191). Nasira, another political prisoner, bears the "electric shocks" but does not betray the trust of Benazir (p. 191). Benazir defends the honour of women and gives them an identity independent to men. When a Cambridge graduate asks Benazir that "marriage would give you (Benazir) a new dimension" then she replies "I restrained myself from saying that a woman doesn't need marriage to give herself a new dimension." In fact, it would be "an honour for a man" to marry her (p. 355). She portrays that women are not submissive creature but can bear oppressors' brunt.

Benazir takes over her father's political legacy — an exceptional example in traditional Pakistani society. Her father's ring that he, Zulfikar Ali Bhutto, wants to "go to Benazir" after his death, symbolises her father's intention to pass his political legacy to his daughter, Benazir (p. 9). She inherits her father's political legacy in shattered condition and introduces a new wave of ambition in Pakistani people. Where Benazir becomes an orphan after her father's death, she becomes the caretaker of the "orphan" nation left by her father at the same time (p. 168). Being the eldest, she legitimises her inheritance of political legacy that her parents has given her "charge" to look after the family matters after them (p. 33). She takes her responsibility as an elder sister and tries to keep calm in her brothers and sister's life after her father's demise. Benazir has inverted many things in her familial life and the world of politics. She is the first 
woman who is democratically elected as head of any Muslim country and even ahead of most Western countries. She has eliminated the gender stereotypes associated with daughter.

\section{Analysis of Songs of Blood and Sword: A Daughter's Memoir}

Fatima's narrative can be divided into three major parts. One part deals with Bhutto's family's history, and specifically, it glorifies her grandfather, Zulfikar Ali Bhutto. The second part of the book provides a detailed background to her father's struggle to avenge Zia's military government that hanged his father. In the third part of the book, Fatima defends her father's political legacy and unveils the corruption of her aunt Benazir and her husband's (Zardari's) government. While defending her father's actions and choices she maintains her own individuality. She comes up with her individual choices, likings and dislikings. She defines herself as independent 6from her father. She relates herself to her father only on physical grounds as she mentions that most of her father's friends in their interviews mention that $\mathrm{I}$ resemble my father. Still, her claim of such relational identity to her father becomes vague when she mentions that she has also been complimented in her childhood that she is "just like" her aunt Benazir, the woman she dislikes the most (p. 269). Fatima is well aware of her father's risky life, and she wants to be safe if something happens to him. She asks her father about her guardianship because she does not want to go her biological mother, Fowzia. She defends her father's choice to divorce her mother that it was all about to do with her uncle Shah's death. To some extent, Fatima is convinced of the accusation of Raehana (Fowzia's sister, and the wife of her uncle Shahnawaz) for her uncle's murder which leaves her father in pain and helplessness. She mentions that she was introduced with very grown-up words by her father in her childhood like the word divorce. Her father sat her down and tried to understand her meanings of divorce. Fatima's unusual childhood was surrounded by the grown-ups, other than the family members, because of her father's choice of self-exile. As a child she was conscious that things around her were not normal, her grandfather was assassinated and with her father she was in exile. Fatima narrates that her heart was too filled with her father's love, on which she "selfishly" depended and couldn't gave some space to her mother (p. 264). Although her narrative gives the impression that she has lost maternal love, she couldn't connect emotionally to her mother. She did not want 
to know others about her biological mother, Fowzia. She develops her identity as a Bhutto family's "firstborn grandchild" (p. 269), which gives her a distinctive position in the family.

Further, she mentions that though she had sensed the tension between her father and aunt Benazir, she did not take her father's side because she has her own relationship with her aunt (p. 269). Fatima comes out with different identities with different names as she narrates that her father called her "Fatushki" when they were being funny and joking around, "Fati" when they were being serious and intellectual and "Fatima" when he father was angry at her (p. 271). After mentioning her identities, she cites her intellectual identity. when her father asked her to pray for Palestinians because they were also homeless like them, she replies that if I ask God to send Palestinians back to their home, what if he "forgets about us?" (p. 271). Fatima does not compromise on her self and its feelings. She does not want to look embarrassed in front of others. She is furious with her father when he infuriates her in front of her new friend, so she threatens to send him to Fowzia. In another instance at school, when she hears gunshots, she tells the boys to lay on the ground because she is afraid of looking afraid.

Fatima narrates that Benazir has sought power at the cost of her brothers' and father's lives. She compromises their political murders and does not open any inquiry of their murder cases. Jacques Vergès, a French lawyer who was hired for the Shahnawaz murder case, explains to Fatima that "I wanted to make a big scandal about Shah's murder . . . but Benazir was against it" and she didn't want to fight the Pakistani Intelligence service and the CIA. Murtaza was always convinced that they were behind his brother's death (p. 258). Fatima gives the reason for Benazir's disapproval to the inquiry of Shah's murder since her power was based on CIA and Pakistani Intelligence service and she did not want to lose it. Fatima analyses that the benefit from Shahnawaz's death she could get was nothing "I had ever imagined before" (p. 257), and she further mentions that but "I knew, from experience, that anything is possible in the Bhutto family" (p. 257). Her platform is dependent on populism (Benazir, 1994, p. 196) and she can die for her father's concept of democratic leadership (Fatima, 2011, p. 289). However, she is reluctant to democratise and strengthen her organisation. Benazir is posing to benefit from it will be the daughter of a democratic parent has just. Fatima criticises democracy, calling it a slogan rather than a governance style in Pakistan (p. 241). for the sake of gaining power, Benazir bends 
her father's murderers' fingers like the oath of office takes Ghulam Ishaq Khan, who served under the Zia regime as the chairman of the senate like this. He was first to be the governor of Sindh and, having signed the death warrant of her father, remains in power under her first-term administration (p. 237). It's unthinkable for Fatima to work with her father's assassins. Fatima blames Benazir to work with General Zia because he was killed in a plane crash. influence was given to her brother's assassins, Waj Durrani and Shoaib Suddle, who assisted in his (their) death (p. 416).

Fatima points out Benazir's insensitivity when she bars her mother from visiting her husband's grave — an act that even General Zia's junta had never done (p. 347). Ghinwa tells Fatima that under Benazir's government, her mother, police open fire at Nusrat and barely missed her and killed two boys who secured Mrs Bhutto's life (p. 347). Skard (2015) mentions that according to Anderson, Benazir felt betrayed by her mother when she preferred her son Murtaza for her husband's political legacy. Nusrat speaks to "New York Times" that Benazir talks a lot about democracy, "but she's become a little dictator. I can't forgive her" (p. 348). Benazir justifies her shooting orders by claiming that there were "RAW agents" firing at "us" in the crowed protesting for Ms Nusrat's right to visit the grave (p. 349). Fatima here makes the point that there is no difference between police and Benazir, that Benazir has used the inclusive pronoun "us" for police. According to Fatima, police was just complying with Benazir's orders and it was the same police who brutally assassinates her father. Nusrat continues speaking to New York Times and shares that "Benazir tells a lot of lies", and she has become "paranoid about her brother (Murtaza)" (p. 349). Fatima's criticism of Benazir is because of the exploitation of her father's right to inheritance at her hands. Fatima shows the incompetency of Benazir as a political leader as she becomes overexcited over the hijacking of the plane and makes a mistake of making jubilant calls to her friends that "we did it ... we finally got them (military regime)" and immediately police arrives and arrests Nusrat and Benazir. After her arrest she backtracks that "it wasn't 'our people'" and she is not involved in the hijacking. Fatima ironically writes that Benazir became "innocent," a "Muslim Aung San Suu Kyi, a Pakistani Gandhi" at the cost of her brothers who were declared as terrorists (p. 229). 
Fatima mentions that it was not only Benazir's brothers and mother who suffered at her hands but she also created difficulties for her nieces Fatima and Sassi. Sassi, her cousin and Shahnawaz's daughter, wants to visit her father's grave in Pakistan. Still, Benazir and many others on her side do not want us "finally getting together" like our fathers (p. 256). She points out that Benazir does not "allowed" us to meet our grandmother (p. 421). She asks her aunt about all her wrongdoings with her father but "she never answered" (p. 420) her questions. Her pain at her father's killing is comparable to Benazir's. Benazir torn apart at her father's assassination, cannot feel what she is doing with Murtaza and his daughter (Fatima). One of her father's sisters Benazir inherits her father's political legacy and the other Sanam files a case against Fatima's younger step-brother Zulfi, Ghinwa and Fatima for the ownership of property (p. 421). Fatima discloses her aunts' "silly" act of secret smoking with leather hand gloves on and covered hairs with wet towel to save their nails and hair from the smoke (p. 86). The more she discovers Benazir's rivalry for her father, the more she becomes distanced from her aunt (p. 361). Fatima's disliking her aunt becomes more evident when expresses her desire not to live in "Benazir's old room", even she does not want to live with her things and asks her grandmother if her aunt could come and "take her things" (p. 334). Fatima concludes that the legacy Benazir has left behind is just corrupt and seeks a dynastic elite politics (p. 433).

Almost one-third of Fatima's autogynography is dedicated to her grandfather Mr. Zulfikar Ali Bhutto. Fatima narrates that Zulfikar was a spirited and intellectually determinant politician (p. 57). She sheds light on her grandfather's political genius. Begum Mazari's voice adds more adjectives to her grandfather's character and informs that Zulfikar was a very "progressive" man who had broken many Pakistani culture taboos. He is the first in his family who takes his wife everywhere with him, even on "state trips" (p. 55). She is proud of her grandfather's dissent of US policy in Vietnam. Fatima believes that power and violence both together conspire so that injustice prevails. Her grandfather was not a power seeker, but he resigned from his foreign minister's post in his protest against General Ayub's acceptance of the Tashkent Declaration. It renders him a hero in the eyes of the Pakistani people. His resignation expands his popularity among the political activists, ordinary people, students and workers (p. 68). Fatima admires that under Zulfikar's leadership, Pakistan has enjoyed the most substantial period of the Pak-Chinese 
relationship. He opens Pakistan foreign policy to numerous other Muslim and Asian states (p. 108). Fatima mentions that "politics is nothing if not personal" (p. 114). Zulfikar ignores his personal interests and seeks to amend the injustices of "feudalism" by introducing land reforms (p. 113). Fatima praises her grandfather's political vision and gives reasons for the downfall of his government. She incorporates Sardar Marri's voice, who tells Fatima that "Bhutto was no different from Hitler" because of his operation in Baluchistan on the Shah of Iran's persuasion (p. 118). Fatima writes that Zulfikar lost his power and popularity with his own hands by fighting against the ordinary Pakistanis who were the source of his "ultimate strength" (p. 119).

Fatima's narrative is based on the reciprocatory role of genders. Although women are more affected by their assigned gendered roles, Fatima believes that men have also been as badly victims as women, with the difference that men's issues go unnoticed. Since the beginning of her childhood, Benazir kept an eye on Murtaza and wanted the same that he had. Fatima notes the sibling rivalry found between her father and Benazir by including her narrative's anonymous voice. Zulfikar's old family friend observes that Benazir wanted the same toys that Mir had. Her parents try to make her understand that boys' toys are different from the girls', but she insisted. Benazir snatches toys from her father in childhood and, later on, she confiscates his right to political inheritance in adulthood.

Like Benazir, Fatima does not construct her Muslim identity. Still, she comes out as a westernised woman when she suggests her father that he should feature somewhere in his party's manifesto the "abortion freedoms as well as free access to contraceptives" (p. 390). Further, she suggests her father that there should also be "AIDS awareness and treatment programmes" (p. 390). Fatima was 12 years old when she offers her father about abortion freedom and it is quite young age to understand the issues like abortion freedom. In fact, it is her gender sensitivity that she claims for women the right to their own bodies. She raises her voice for women that they should be free to make choices regarding their own reproduction and sexuality. Further, she mentions that women should have a right to access the services, medicine and information needed to support their choices regarding their reproduction. The denial of women's control over their own bodies sustains women's sexual, social, economic and political subordination. Ruether (2012) supports Fatima's argument that patriarchy means "the subordination of women's bodies, 
sexuality, and reproduction to male ownership and control" (p. 305). Burrowes (1996) mentions that according to Rosalind Miles, patriarchy denies women's fundamental human needs like their freedom, control, autonomy and the fundamental right of "control over their own bodies" (p. 137). Fatima projects her femininity as at the age of fourteen when she starts wearing lipstick but her father disagrees that she is pretty young for that but she insists that she is now grown up as she will be "fourteen" that year (p. 392).

\section{Conclusion}

Benazir's political consciousness enables her to secure herself the prime minister's title for two terms. Benazir cannot take an independent career and submits to her father's choice of a political career. She is aware of politics' risky life, but she takes the risk that her father took, and that finally takes her own life. Many other women in her narrative stand by her side and raise their voice for Zia's military regime's unjust treatment. Although Benazir portrays herself as a strong woman, yet she wants an escape from the dreadful memories of her father's imprisonment, death and her own detentions at the hands of the dictatorship. She bears the brunt of dictator's injustices but does not leave the pursuit of her father's dreams.

Fatima defends her father's political legacy and holds her aunt Benazir as the usurper of the inheritance right of her dad. She narrates her aunt's corruption and insensitivity and her husband, Zardari. She praises her father's diplomatic strategies with two-fold effects; in the first, her father is not in favour of violence. In the second, her father has diplomatic insights for political leadership. Fatima praises her grandfather's political achievement and then relates them to her father's. She constructs her father's relational identity with her grandfather Zulfikar on account of his political successes. On the other hand, she narrates the conflicts of Benazir's politics with that of her grandfather, Zulfikar. Besides her father's political and diplomatic genius, Fatima portrays a humble image of her father.

Both the narrators have used the narrative strategies that best suit their purposes according to the context of their writing as Smith and Watson (2006) hold that autobiographical narratives are motivated by particular audiences, desires and contexts of publication. The autogynographies are marked by non-chronological order because of the subsequent interruptions by different persons and their anecdotes. The reader cannot relate to or connect the 
various events narrated in the books. Jelinek (2004) explains that women begin their selfnarratives in chronological order but it soon disappears usually unconscious interruptions by the "anecdotes, even out of order, and all kinds of insertions-letters, articles, even descriptions by others" (pp. 187-88). Multiple voices support and validate the arguments of the narrator. At the same time, they cease the coherence of their narrative.

Benazir and Fatima record their inner realities at the demise of their fathers in their narratives. The significant feature of these autogynographies is the element of universal women's feelings to defend their father's image. These autogynographers externalise their inner experience and subvert patriarchal stereotypes. The female autobiographers claim their kinship in the narratives and seek to disrupt the culture's production of the daughter and her relegation to the private sphere. They subvert those power hierarchies that only a man is supposed to stand against. The context of the autogynographies reveals various experiences within which women are forced to live. The study provides a vital perspective on how women construct their self, identity, reality, truth and world out of the web of relationships. Though these autogynographers sometimes exaggerate while praising their fathers, yet they reveal some facts.

\section{References}

Allen, P. (2000). The small group process. In B. A. Crow (Ed.), Radical feminism: A documentary reader (pp. 277-281). New York: New York University Press.

Bhutto, B. (1989). Daughter of the east. London: Hamish Hamilton.

Bhutto, F. (2011). Songs of blood and sword: A daughter's memoir. New York: Penguin Books.

Burrowes, R. J. (1996). The strategy of nonviolent defense: A Gandhian approach. Albany: State University of New York Press.

Derr, M. K., MacNair, R., \& Naranjo-Huebl, L. (2005). ProLife feminism: Yesterday and today. Kansas City: Feminism and Nonviolence Studies Association.

Hanisch, C. (2000). The personal is political. In B. A. Crow (Ed.), Radical feminism: A documentary reader (pp. 113-116). New York: New York University Press.

Jelinek, E. C. (2004). Tradition of women's autobiography. New Jersey: Xlibris Corporation. 
UNIVERSITY OF CHITRAL JOURNAL OF LINGUISTICS AND LITERATURE

VOL. 4 | ISSUE II | JULY - DEC | 2020

Khaliq, R., \& Khan, M. (2018). Genderlect Styles: Analysis Of Ibsen's “A Doll's House” From The Perspective Of Gender Differences In Language Use. University Of Chitral Journal Of Linguistics \& Literature, 1(I), 36-46. doi:10.33195/jll.v1iI.148

Kristeva, J. (1980) Desire in language: A semiotic approach to language and art. Trans. T. Gora, A. Jardine \& L. S. Roudiez, ed. L. S. Roudiez. New York: Columbia University Press, Print.

Lee, T. M. L. (2007). Rethinking the personal and the political: Feminist activism and civic engagement. Hypatia, 22, (4), 163-179.

Mortenson, J. (2011). "Femininity," social construction of.In M. Z. Stange, C. K. Oyster \& J. Sloan (Eds.), Encyclopedia of women in today's world(pp. 528- 531). Thousand Oaks, Calif: Sage Reference.

Panchappa R. W. (2011). Mikhail Bakhtin's dialogism and intertextuality: A perspective. Indian

Streams Research Journal. 1, 4, 37-41.

Passerini, L. (1987). Fascism in popular memory: The cultural experience of the Turin working class.(R. Lumley \& J. Bloomfield, Trans.). Cambridge: Cambridge University Press.

Raj, P. Prayer Elmo. (2015). Text/Texts: Julia Kristeva's concept of intertextuality. Journal of Humanities and Social Sciences, 3, 77-80.

Raza, S. (2014). Bilawal may be wary of the veterans of his party: The young Bhuttomknows being soft on the PML-N will not be a great start. The Friday Times. Retrieved from

http://www.thefridaytimes.com/tft/the-uncles-of-ppp/

Rosen, R. (2000). The world split open: How the modern women's movement changed America. New York: Viking Books.

Royce, T. (2011). "Femininity", social construction of.In Z. Stange, C. K. Oyster \& J. E. Satchidanandan, K. (2010). Reflections: Autobiography today. Indian Literature, 54, 6-9.

Ruether, R. (2012). Twentieth-century feminist and womanist ethics: Sexism and God-talk. In G. W. Forell \& J. M. Childs (Eds.), Christian social teachings: A reader in Christian social ethics from the Bible to the present. Philadelphia, Pa: Fortress.

Seely, M. (2007). Fight like a girl: How to be a fearless feminist. New York: New YorkUniversity Press.

Skard, T. (2015). Women of power: Half a century of female presidents and prime ministers worldwide. Bristol: Policy Press. 
Sluga, H. (2014). Politics and the search for the common good. Cambridge: Cambridge University Press.

Smith, S., \& Watson, J. (2006). Introduction: Living in public. In S. Smith \& J.

Watson (Eds.), Before they could vote: American women's autobiographical writing (pp. 3-24). Madison, Wis: University of Wisconsin Press.

Smith, S. (1998). Performativity, autobiographical practice, resistance. In S. Smith \& J. Watson (Eds.), Women, autobiography, theory: A reader (pp. 108-115).

Stanton, D. C., \& Plottel, J. P. (1984). The Female autograph. New York: New York Literary Forum.

Tong, R. (2009). Feminist thought: A more comprehensive introduction. Boulder: Westview Press.

Walters, M. (2005). Feminism: A very short introduction. Oxford: Oxford University Press.

Widmalm, S. (2016). Political tolerance in the global South. London: Routledge.

Williams, J. A. (2001). The personal is political: Thinking through the Clinton/Lewinsky/Starr Affair. Political Science \& Politics, 34, 1, 93-98.

(C) 1020 by the author. Licensee University of Chitral, Journal of
Linguistics \& Literature, Pakistan. This article is an open access article
distributed under the terms and conditions of the Creative Commons
Attribution (CC BY) (http://creativecommons.org/licenses/by/4.0/).

